\title{
Family Support System Among Recovering Adolescent Drug Addicts : A Case Study
}

\author{
Mohd Fitri Amir Shoodi ${ }^{1}$, Abu Yazid Abu Bakar ${ }^{1 *}$, Ku Suhaila Ku Johari ${ }^{1}$, Dharatun \\ Nissa Puad Mohd Kari ${ }^{1}$, Norhafizatulhusna Ismail ${ }^{1}$
}

${ }^{1}$ Faculty of Education, Universiti Kebangsaan Malaysia, 43600 Bangi, Selangor, Malaysia

*Corresponding author. Email: yazid3338@ukm.edu.my

\begin{abstract}
The family support system gives an impact among recovering adolescent. The aim of this study is to explore the element of support system among recovering adolescent drug addicts using sandtray therapy approach. This is a case study involving four recovering adolescent at the Clinic Cure \& Care Clinic, National AntiDrug Agency, Kota Bharu, Kelantan. The thematic process was used to analyze the process of group sandtray therapy and the arrangement of the miniature in the sandtray. The findings show that recovering adolescent drug addicts need family as a support system, however their families were not functioning in the prevention and recovery process. Besides that, the results show that there are three vital themesof family support system, namely: 1) family issues, 2) family structure and 3) ideal family characteristics.
\end{abstract}

Keywords: Addiction counseling, support system, family, adolescent drug addicts

\section{INTRODUCTION}

Drug addiction is a growing social problem amongst the nation and results in hundreds of thousands of cases among adolescents and adults. The National Anti-Drug Agency and the authorities play a role as a platform to combat the addiction of drugs. Statistics show a dramatic increase in adolescent drug addicts from 2013 to 2017 from the National Drug Agency's Official Statistics (AADK) website. This causes no individual awareness about the dangers of drugs.

Family is one of the most important social support among teenagers. According to Brannon and Feist (2004) social support is material and emotional support is thus received from others. In addition, social connections or social networks that refer to individual numbers are also linked to social support. The emotion inherent in a family affects behavioral formulation compared to parenting skills (Amran Hassan, Fatimah Yusoff \& Khadijah Alavi 2014)

According to Hsueh and Yoshikawa (2007), a wellfunctioning family empowers the aspect of

\section{Family Support System}

A holistic family support system is a system that provides support to families in resolving family disputes especially when the dispute involves legal and conflict issues involving the emotional, mental and social domain (Mohd Arshad, 2017). According to Aizan Sofia Amin, Jamiah Manap, and Noremy Md End (2016), support from family members is very important as it can help them live a good and quality life. Ferlis (2012) stated that someone was happy and satisfied when their guardians consisting of parents and siblings worked together to provide them with emotional, physical and moral support. The emotions that existed in a family greatly influenced the formation of a behavior compared to to parenting skills especially to individual behavioral problems (Amran Hassan, Fatimah Yusoff \& Khadijah Alavi, 2014).

Sand Tray Therapy

Sand tray therapy is one of the therapeutic approaches that provide opportunities for individuals to experiment with themselves creatively and verbally and to assist clients in identifying their subconscious impulse (Roubenzadeh et al., 2012). It is also an effective method for counselors to explore the client's inner world with clients as well as to see event interpretation and communication through the symbols exhibited in the sand tray (Ramsey, 2014). According to Zuriyati Seman et.al (2017), sandwheel therapy can be performed by counselors directly and indirectly. An indirect approach helps counselors explore issues and issues that clients want to share according to clients' needs.

Research Objective

The main objective of this study is to explore the family support elements among drug addicts.

\section{METHOD}

This research is conducted qualitatively using a case study design to answer questions about the phenomenon 
to be studied (Cresswell, 2018: 2014: 1998). Phenomenon mentioned here is drug addiction among adolescents. The participants of this study were four teenagers involved with drug addiction from the National Anti-Drug Agency, Cure \& Care, Kota Bharu, Kelantan. In this study, data were obtained from in-depth interviews observations on the process of sand tray therapy during the group counseling session and report from the counseling session.

The sand tray therapy method has six implementing protocols, namely: 1) providing space equipped with sand tray equipment, 2) introducing sand tray to clients, 3 ) building representations in sand tray, 4) sand-sharing and exploration of tray, 5) termination and cleaning of sand tray and documentation of the session through counseling reports (Homeyer \& Sweeney, 2016). A total of 4 group counseling sessions were structurally conducted to the participants of the study based on five goals namely, 1) session building relationships, 2)self, 3) family, 4) support system, and 5) hope. Each session lasted for one hour. Each member then develop a picture representation of the sand tray based on the goals of each session and the sharing and exploration of the sand tray. The participants of the study gave meaning to every miniature through the exploration and portrayal of the sand tray at the end of the partnership session.

The researchers use the thematic analysis method for all three data collection techniques manually. Data analysis is done by using the Three C's Analysis of Coding, Categorizing and Concepts based on Litchman (2006), which concludes that this method can help and facilitate the researcher to understand more deeply in each meaning to produce the theme of a phenomenon more effectively and accurately.

\section{RESULT AND DISCUSIONS}

The findings will be discussed based on the information provided by the participant profile and theme emerged. Participant background information will describe the overall client background.

\section{Respondent's Profile}

Table 1 summarizing the client's profile from five aspects; age, gender, number of sibling, latest status and the caregiver.

Table 1 : Participant profile

\begin{tabular}{|l|c|c|c|c|c|c|}
\hline \multirow{2}{*}{ Respondends } & \multirow{2}{*}{ Gender } & age & \multirow{2}{*}{$\begin{array}{c}\text { No. of } \\
\text { Sibling }\end{array}$} & Dad & Mom & \multirow{2}{*}{ Caregiver } \\
\hline KK01 & 15 & Male & $\begin{array}{c}\text { Eldest } \\
\text { Child }\end{array}$ & Died & Died & $\begin{array}{c}\text { Grandmot } \\
\text { her \& } \\
\text { uncle }\end{array}$ \\
\hline KK02 & 16 & Male & 2 of 9 & Died & Live & Mom \\
\hline KK03 & 14 & Male & 1 of 4 & Jail & Jail & $\begin{array}{c}\text { Grandmot } \\
\text { her \& aunt }\end{array}$ \\
\hline & 13 & Male & 3 of 4 & Live & $\begin{array}{c}\text { Critical } \\
\text { Prisease } \\
\text { and, } \\
\text { Paralise }\end{array}$ & Dad \\
\hline
\end{tabular}

KK01 comes from Sabah and resides in Kuala Lumpur. Parents of KK01 have died from childhood. KK01 was raised by her grandmother and uncle. KK01 is the only child. KK01 has close friends and lovers who are a source inspiration and encouragement. However, KK01 has a friend A who has taken KK01 in the drug world through an introductory period of less than one month. Life KK01 is not manageable after being acquainted with A. His life is covered by the drug involvement and uses drugs to satisfy his craving. At the same time, A intends to backstab KK01 to take KK01's lover. KK01's best friends are always there when it comes to KK01's downfall that requires enthusiasm. KK01's close friends often advises him to change his ways away from drug addiction.

KK02 comes from Kota Bharu, Kelantan and is the second child of nine siblings. KK02's father has died of a heart attack. When his father died, his family was broken up due to the absence of his father. His father was a role model for his family. His mother often scolded KK02 when in school compared to home because of his delinquency. Therefore, KK02 takes the easy way out in taking drugs with his school friends. When asked about drug intake, KK02 influenced other partners to take drugs as well and $\mathrm{KK} 02$ was also the highest drug user compared to his friends. KK02 often sits alone at home and does not mingle with family members. KK02 lost the loved one as a role model in his life. KK02 dreamed of a happy family like the one he had before. KK02 wants a family of peace and distance away from the problems that led to the disintegration of family members.

KK03 comes from Tumpat Kelantan and is the first of four siblings. KK03's life before taking drugs was very happy with his family but when KK03 became friends with a motorcycle gang, he got involved in drugs. Before the police raided his home, KK03 did not know his parents were trafficking drugs. Police got 100 kilograms of arrests at his parents' home. KK03 was disappointed and saddened by the actions of his parents. KK03 expects his parents to be released from prison and is guarded by his grandmother and sister. KK03 often quarrel with his siblings on the care of his younger siblings. KK03 is not good at keeping the youngest brother and constantly wants to go out with his friends. When asked what KK03 wants, he wants a family like before playing on the beach and laughing with them. KK03 also wants parents away with drugs.

Finally, KK04 comes from Ketereh, Kelantan and is the third of four siblings. KK04's father works in the village and KK04's mother has a chronic illness causing him to be able to do nothing. The siblings of KK04 often quarrel with his mother's custody. The accusation from the siblings has made KK04 stressed. Ultimately, KK04 takes the easy way to get rid of stress by taking drugs 
from people who often distribute them in the store. His family found out KK04 is taking drugs because of his frequent drug usage. His mother however, often advisse KK04 to change his ways. After that, KK04 was willing to go to Cure \& Care. KK04 loves her mother very much and wants a peaceful family and far away from the problem and wants to see his mother healthy as before.

\section{Emergent Themes}

Generally, the findings show the elements of the family support system for teenage drug addicts to three main themes, namely 1) Family Issues, 2) Family Structure and 3) Expected family support features. These three main aspects are analyzed, given the code and the researchers provide the interpretation of the experiences of each participant. Briefly, the reporting theme is designed to illustrate and understand the experience of the study participants. All the experpts are remain in original language used during interview. This is due to creadibility issues of the data (Corden \& Sainsbury, 2006 ; Dharatun Nissa, 2017).

Table 3.2 : Emergent themes and sub themes

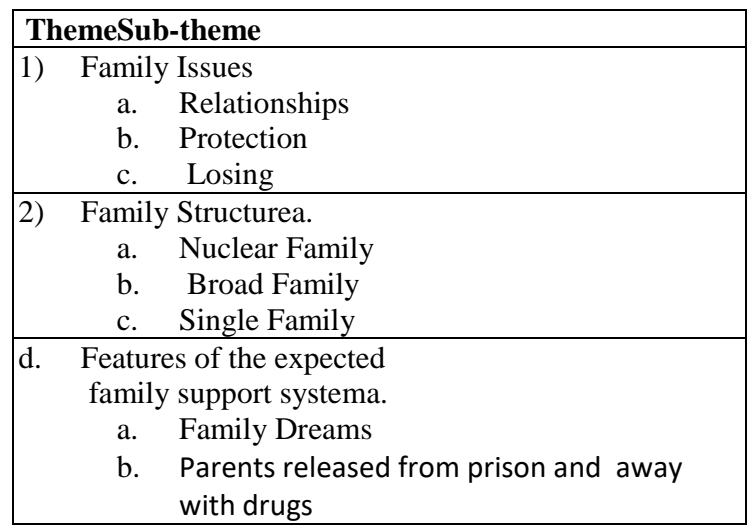

\subsubsection{Family Issues}

Most of the causes that cause adolescent behavior problems to take drugs are caused by conflicts in family relationships. This family issue covers communication, protection and loss.

\subsubsection{Relationships}

Based on the results of the study, the relationship between the participants and family members was distant. Relations of family members involve parents, grandparents, aunts and siblings. This is evidenced by KK02, KK03 and KK04 saying that:

"ayah saya dah meninggal akibat serangan jantung. Bila ayah saya meninggal jee, keluarga saya berpecah belah....."

("My dad died of a heart attack. When my father died, my family was divided....." )
(KK02)

"saya sering bergaduh dengan ibu saudara sebab kena jaga adik bongsu saya....." ("I often quarrel with aunt because I'm in charge of my youngest brother .....")

"abang dengan kakak saya selalu bergaduh nak jaga ibu...."

("I always fight with my siblings to take care of mother ....")

(KK04)

The non-functionality of a family is due to the loss of a role model in the family and this causes various negative feelings such as anxiety, social problems, aggressive and behavior (Amran Hassan, Fatimah Yusoff \& Khadijah Alvi (2014).

\subsubsection{Protection}

The protection aspect refers to care by family members of the participants. The study participants are guarded by grandparents, aunts and uncles. Between protection from KK01 and KK03 study participants

"mak ayah saya dah meninggal sejak kecil lagi. Sekarang saya dibesarkan oleh nenek dan ayah saudara..."

("My father died from childhood. Now I am raised by my grandmother and father ...”)

"bila mak ayah saya masuk penjara, saya dengan adik beradik dijaga oleh nenek dan ibu saudara...."

("When my dad went to prison, I lived with my siblings guarded by my grandmother and aunt .....")

(KK03)

\subsubsection{Losing}

The losing aspect can be explained by the most significant person in the life of the participants. Significant people are role models and parents. It can be proven by KK01, KK02 and KK03 study participants:

"mak ayah saya dah meninggal dah lama semasa saya kecik (kecil)..."

("My father died long ago when I was small (small) ...")

"ayah saya meninggal sebab sakit jantung. Dia yang selalu tegur, marah, nasihat saya dan adik beradik......."

("My dad died because of a heart attack. He is always upset, angry, advise me and my siblings.......") 
(KK02)

"bila mak ayah saya masuk penjara, saya takde tempat nak mengadu dan dapat kasih sayang daripada mereka........"

("When my mom and dad went to prison, I had no place to complain or to obtain love.......")

(KK03)

\subsubsection{Family Structure}

Based on the findings, there are three types of family structure namely nuclear families, extended families and single families.

\subsubsection{Nuclear family}

The nuclear family consists of only parents, mothers, and children. This can be explained by KK03 and KK04 study participants.

"saya anak sulong daripada empat orang adik beradik. Mak ayah saya masuk penjara sebab mengedar dadah, sekarang nenek dengan mak saudara yang jaga kami...."

("I am a senior child of four siblings. My dad went to jail for drug trafficking, now grandmother is the guardian of me and my siblings....")

(KK03)

"saya pula nombor tiga dari empat adik beradik. Ayah saya bekerja kampung jee..mak sakit terdampar kat umah......"

("I'm also the third of four siblings. My dad worked in the village... I am sick of being stranded in the house...")

(KK04)

\subsubsection{Broad Family}

A wide family aspect consists of several generations of grandparents, relatives and cousins living together. This can be proved by KK01 and KK03 study participants as follows:

"mak ayah saya dah meninggal sejak kecil lagi. Sekarang saya dibesarkan oleh nenek dan ayah saudara..."

("My father died from childhood. Now I am raised by my grandmother and father
(KK01)

"bila mak ayah saya masuk penjara, saya dengan adik beradik dijaga oleh nenek dan ibu saudara....."

("When my dad went to prison, I lived with my siblings guarded by my

grandmother and aunt .....")

\subsubsection{Single Family}

In addition, a single family consists of either parent or child. This may be due to divorce or even death. This can be proven by KK02 study participants when his father is dead.
"saya anak nombor dua dari sembilan adik beradik, ayah saya dah meninggal sebab serangan jantung. Sekarang nii saya duduk dengan mak dan adik beradik..."
("I'm the second child of nine siblings, my dad died of a heart attack. Now I'm staying with my mother and siblings ...")

(KK02)

\subsubsection{Features of the expected family support system}

Family support systems are one of the key elements that can affect the development of children. Among the features of family support system expected by drug addicts are a dreamed family and parents are released from prison and away with drugs.

\subsubsection{Family Dreams}

The family that is dreaming here means everyone is dreaming of a happy and harmonious family. This is evident that almost all participants hoped for the dreamed family.

"saya mahukan keluarga yang bahagia seperti dahulu walaupun tiada ayah disamping kami....."

("I want a happy family like before, though father is no longer beside us.")

(KK02)

"apa yang saya mahukan, saya nak keluarga saya macam dahulu selalu bermain di pantai dan gelak tawa bersama dengan mereka...."

("What I want, I want my family to always play on the beach and laugh....")

"saya nak keluarga saya macam dulu..jauh daripada masalah adik beradik dan nak

lihat mak saya sihat macam dulu........"

("I want my family to be like the olden days ...away from sibling issues and I want

to see my mother healthy as well........")

(KK04) 


\subsubsection{Parents were released from prison and away with drugs}

Everyone wants peace and distance with drugs. The results of the study showed that $\mathrm{KK} 02$ and $\mathrm{KK} 03$ researchers wanted their family away from drugs.

"walaupun saya ambil dadah, saya nak adik saya nombor empat jauh dengan dadah..sebab saya tahu dadah tu lebih bahaya dari segalanya....."

("Even if I take drugs, I want my fourth younger brother to be away with drugs ... anything.....")

Because I know drugs are dangerous than

"saya harap mak ayah saya bebas dari penjara...saya nak mak ayah jauh dari dadah...."

("I hope my parents will be free from prison ... I want them away from drugs ....")

(KK03)

\section{DISCUSSION}

The results of this study are to understand the elements of the family support system for teenage drug addiction and experience that can be seen from the aspect of family issues, family structure and features of the expected family support system. In this study, the Adlerian theory approach was used in the sand tray session among participants. This approach emphasizes the support system within a family. In addition, the findings show loss of significant people in life affects the life of the participants. In parallel with Amran Hassan et al. al (2014) the family's dysfunction is due to the loss of a good role model and causes various negative feelings that arise such as anxiety, social problems, aggressive behavior and so forth.

Overall, the results of the study showed that participants of the study wanted their parents and their parents free of drugs and dreamed of a good relationship with the family. The results of the study are in line with the study of Fauziah Ibrahim et. al (2014) stating that good family ties are also capable of reducing feelings of inferiority among former drug addicts who are struggling to recover from the effects of drugs and thus increase the success of recovery from drug influences. Based on the findings, participants who continued to maintain longterm family social support, had a more meaningful life. It coincides with the results of Fauziah Ibrahim et al. al (2014); Gruber and Fleetwood, (2004) which shows similar results.

\section{CONCLUSION}

Based on the study conducted on drug addiction among adolescence, having weak family support system gives emphasis on family members. This group requires the attention of all members to assist in the recovery among teenage drug addicts. This study provides a deeper understanding for researchers in exploring elements of the family support system. Hence, the study proposes quantitative studies to identify support systems among juvenile recovery in a larger sampling.

\section{REFERENCES}

Aizan Sofia Amin, Jamiah Manap, \&amp; Noremy M Akhir (2016). The Role of Family in the Lives of Disabled Malaysian Children. Journal Academica, 86(1).

Amran Hassan, Fatimah Yusoff \& Khadijah Alavi, (2014).Pengaruh Faktor Kesepaduan (KefungsianKeluarga)dan Kemahiran Keibubapaan Terhadap Kesejahteraan Psikologi Dalam Kalangan Ibubapa danAnak. Sains Humanika 3:1, 99-105.

Brannon, L., \& Feist, J. (2004). Health psychology: An introduction to behavior and health. Singapore: Thomson Wadsworth.

Corden, A., Sainsbury, R. 2006. Using verbatim quotations in reporting qualitative social research: researchers' views. ISBN 978-1- 871713-98-5.

Dharatun Nissa. (2017). Strategi Daya Tindak dalam Kalangan Ibu Tunggal Kematian Pasangan. (Doktor Falsafah). Universiti Malaya.

Fauziah Ibrahim et. al (2014). Pengguna Dadah Wanita di Malaysia : Pengalaman Penagihan dan Hubungan Kekeluargaan. Jurnal Teknologi (Social Sciences). 67(1): 17-25.

Ferlis Bullare @ Bahari. 2012. Using Grounded Theory for Studying Meaningful Happiness among People with Physical Disabilities in Malaysia. Kertas kerja dibentangkan di Seminar International Conference on Psychological Sciences and Behaviors (ICPSB 2012), Jun 2012, Hong Kong.International Proceedings of Economics Development and Research, 40: 110-115.

Hsueh, J. A, dan Yoshikawa, H. (2007). Working nonstandard schedules and variable shifts in Low-income families. associations with parental psychological well-being. Developmental Psychology, 43(3), 620-632.

Homeyer, L. E \& Sweeney, D.S. (2016). Sandtray Therapy : A Practical Manual Second Edition. New York: Routledge

Lichtman, Marilyn (2006) Qualitative Research inEducation. A User's Guide, Sage Publications Inc. California.

Mohd Arshad, (2017). Ke arah memantapkan sistem sokongan keluarga di Malaysia: Pendekatan holistik dalam penyelesaian pertikaian keluarga.

Nor Ba'yah Abdul perincinan Kadir \& Asmawati Desa (2004). Social support and cheerful: A preliminary study of higher learning institutions. Journal e-Bangi. 3(3), 112 .

Nur Shakila, I. \& Ku Suhaila, K. J. (2015). Aplikasi Terapi Sandtray dalam Proses Kaunseling. Jurnal Perkama. 19(9), 121-134.

Ramsey, L.C., (2014). Windows and Bridges of Sand: CrossCultural Counseling Using Sand Tray Methods. Social and Behavioral Sciences, 159, 541-545.

Roubenzadeh, S., Abedin, A. \& Heidari, M., (2012) Effectiveness of SandTray Short Term Group Therpay 
with Grieving Youth. Procedia-Social and Behavioral Sciences, 69, 2131-2136.

Siti Ruslan. (2009). Penyalahgunaan dadah dalam kalangan remaja. Laporan Projek Ijazah Sarjana Muda

Kaunseling. Sarawak: Universiti Malaysia Sarawak

Suppiah Nachiappan (2015). Analysis of Contributing Factors Towards Misuse of Drugs and Rehabilitation Efforts in Terms of Cognition in PENGASIH Centres, Malaysia. Journal of Social Science. 1, 34-39.

Zuriyati Seman et. al (2017) Eksplorasi Terapi Sandtray Kes Pelajar Bermasalah Tingkah Laku. Proceeding International Seminar Counselling 2017. 